\title{
ANALIZA I ZASTUPLJENOST PRIMJENE MODELA OTPUŠTANJA KAPITALA IZ VRIJEDNOSTI NEKRETNINA MEĐU STARIJOM POPULACIJOM U EUROPSKOJ UNIJI
}

\author{
EQUITY RELEASE SCHEME MODELS ANALYSIS AND USAGE \\ AMONG SENIORS IN THE EUROPEAN UNION
}

SAŽETAK: Obrnuto hipotekarno kreditiranje, kao izvorno i dominantno primjenjivana američka tehnika financiranja starije populacije na osnovi vlasništva nad stambenom nekretninom, u posljednjih desetak godina počelo se primjenjivati i širiti na ostatak svijeta pa tako i na pojedine zemlje Europske unije. U Europskoj uniji otpuštanje vrijednosti nekretnine bez njene prodaje ili uz zadržavanje prava ostanka u nekretnini, osnovno se provodi kroz kreditni i prodajni model specifičnog hipotekarnog financiranja namijenjenog starijoj populaciji. Kreditni model u tom smislu podrazumijeva tehniku obrnutog hipotekarnog kreditiranja odnosno doživotnu hipoteku. U radu se stoga detaljnije analiziraju specifični modeli povlačenja novčanih sredstava na osnovi vrijednosti nekretnine namijenjeni starijoj populaciji, uz poseban osvrt na kreditni model ili doživotnu hipoteku koja u biti ne uključuje prodaju nekretnine niti tradicionalnu otplatu kredita, sve do smrti ili preseljenja korisnika takvog kredita. Cilj rada je ukazati na prednosti i nedostatke takvih modela povlačenja novčanih sredstava te na zastupljenost njihove primjene na tržištu Europske unije, uz osvrt na čimbenike koji indiciraju potencijal za njihovu širu primjenu odnosno potencijalno utječu na trendove u razvoju ove industrije. Deskriptivno statistička i korelacijska analiza će se provesti za potrebe ukazivanja na mogućnosti sheme otpuštanja kapitala na osnovi vrijednosti nekretnine u rješavanju financijskih problema starije populacije. Rezultati istraživanja omogućit će bolji uvid u mogućnosti, potencijale i modele povlačenja sredstava iz vrijednosti stambenih nekretnina za potrebe rješavanja financijskih problema pomoću inovativnih financijskih proizvoda namijenjenih starijim osobama.

KLJUČNE RIJEČI: shema otpuštanja kapitala, prodajni model, kreditni model obrnuta hipoteka, starija populacija.

Dr. sc. Branka Tuškan, docentica, Ekonomski fakultet Zagreb, Trg J .F. Kennedyja 6, Zagreb Ana Andrašić, univ. bacc. oec., studentica, Ekonomski fakultet Zagreb, Trg J. F.Kennedyja 6, Zagreb 


\begin{abstract}
Reverse mortgage as financing technique intended to seniors is originally and dominantly used in the USA. Homeownership is the main precondition for its usage and in the last ten years is spreading over the rest of the world and in some member states of the European Union. In European union, home equity release or reversion schemes intended to seniors, without home selling or moving, are realised through two specific mortgage financing models, loan and sale model. Loan model under equity release scheme in that sense is lifetime mortgage which is the most similar to the reverse mortgage technique in the USA. In the paper there are analysed specific money withdraw models on the basis of home equity value intended to senior population, with special remarks on credit model or lifetime mortgage. Lifetime mortgage in that sense includes neither home selling nor traditional loan repayment, all until death or moving of borrower. The main goal of this research is to point out the main advantages and disadvantages of different money withdraw models under equity release schemes and their presence on the European Union market with remarks on the factors that indicate wider usage potential and potentially could have stronger influence on the further development trends in this part. Descriptive statistics and correlation analysis are used for the purpose of analysis of home equity release usage and its potential in financing among older population. The results of analysis would help in bringing more precise conclusion about credit model of equity release and its role in solving finance problem of senior homeowners.
\end{abstract}

KEY WORDS: equity release scheme, sale model, loan model, reverse mortgage, seniors.

\title{
1. UVOD
}

Obrnuto hipotekarno kreditiranje je novija i jedinstvena tehnika financiranja namijenjena starijoj populaciji koja je „,bogata nekretninama, ali siromašna novcem“, a koju sve više nude kreditne institucije u brojnim razvijenijim zemljama. Starija populacija često je financijski i socijalno isključena skupina društva, uslijed niskih ili nikakvih tekućih primanja u razdoblju nakon umirovljenja, a što za posljedicu, između ostaloga ima i ograničen pristup tradicionalnim kreditima. Ako osim tekućih primitaka od mirovine nema drugih priljeva sredstava ili ušteđevine, starija populacija se često suočava s poteškoćama u podmirivanju financijski zahtjevnijih, ali često i osnovnih životnih potreba. S druge strane, ista kategorija često posjeduje vrijedne stambene nekretnine, ali koje ne žele prodati ili iz kojih ne žele iseliti. Stoga, izazov predstavlja i nameće se pitanje kako vlasnici mogu izvući novac iz svoje vrijedne, ali inače nelikvidne stambene nekretnine, bez njene prodaje ili preseljenja, ali i bez zaduživanja, primjerice tradicionalnim hipotekarnim kreditima. Pritom je čisto i potpuno vlasništvo ključni preduvjet za mogućnost povlačenja sredstava na temelju vrijednosti nekretnine. U Europskoj uniji je takvo izvlačenje likvidnosti iz nekretnine omogućeno starijoj populaciji, primarno umirovljenicima, kako bi nadopunili svoj budžet i tekuće primitke od mirovina, u okviru sheme otpuštanja kapitala kroz kreditni i prodajni model. Prodajni model u biti uključuje prodaju nekretnine i isplatu vlasnika, ali uz istodobno sklapanje ugovora o najmu s novim vlasnikom pa nema preseljenja, no kreditni model ili doživotna hipoteka ne uključuje prodaju nekretnine s obzirom da je riječ o kreditu, ali i ne zahtijeva tradicionalnu otplatu kredita sve do preseljenja, prodaje nekretnine ili smrti ko- 
risnika. U tom smislu doživotna odnosno obrnuta hipoteka kao nekonvencionalni kreditni instrument za čije odobravanje je u fokusu primarno vrijednost nekretnine i koji omogućava ostanak u nekretnini, može biti prihvatljivo rješenje za pribavljanje financijskih sredstava u krajnjoj nuždi, primarno namijenjenih za podmirenje neodgodivih i kapitalno zahtjevnijih financijskih izdataka. U ovom radu stoga se analiziraju općenito modeli povlačenja sredstava iz vrijednosti nekretnine namijenjeni starijoj populaciji u Europskoj uniji, a u fokusu je pritom doživotna hipoteka kao inačica izvorno američke tehnike obrnute hipoteke te njena usporedba s prodajnim modelom. Cilj rada je objasniti razlike modela povlačenja sredstava iz vrijednosti nekretnine, ukazati na njihovu postojeću zastupljenost, razmjere te ograničenja primjene na tržištu Europske unije, uz osvrt na čimbenike koji indiciraju potencijal šire primjene.

\section{PREGLED LITERATURE}

Postojeće analize i istraživanja vezana uz proizvode i modele otpuštanja kapitala iz vrijednosti nekretnina među starijom populacijom usmjerena su uglavnom na pojedinačnu analizu modela, primarno obrnute hipoteke i to uglavnom na američkom području, ili su stručnog značaja. Tek manji broj radova bavi se komparativnom analizom i znanstvenim pristupom u istraživanju modela otpuštanja kapitala iz vrijednosti nekretnina prisutnih na europskom području.

Gwizdala (2015.) tako u svom istraživanju analizira obrnutu hipoteku, njene prednosti i nedostatke, preduvjete i ograničenja primjene i u skladu s tim procjenjuje potencijal primjene na poljskom financijskom tržištu, primjenom SWOT analize. Unatoč već dokazanim brojnim prednostima korištenja obrnute hipoteke u specifičnim okolnostima, a na koje autor u radu ukazuje, te pomacima u stvaranju preduvjeta za uvođenje kako u pravnom smislu, pripremom zakona, tako i u smislu približavanja odnosno upoznavanja starije populacije u Poljskoj s konceptom obrnute hipoteke, za njegovo uvođenje i primjenu postoje i presudni bi mogli biti nedostaci takve tehnike povlačenja sredstava ukazuje autor, posebice ako i demografski i socio-ekonomski pokazatelji nisu za to povoljni. Rezultati istraživanja odabranih demografskih, socio-ekonomskih, pravnih te kulturoloških čimbenika specifičnih za Poljsku u tom smislu ukazuju na ograničen potencijal za primjenu obrnute hipoteke. Navedeni čimbenici nisu povoljni i mogli bi predstavljati značajnu prepreku odnosno ograničenje u dijelu potencijalne potražnje, ali i ponude obrnute hipoteke, a autor posebice ukazuje na nepodudarnost koncepta obrnute hipoteke s postojećom vezanom regulacijom u tom dijelu.

Coda Moscarola, F. et al. (2015.) temeljem analize dohotka i stambenog bogatstva starije populacije na europskom području zaključuju kako udjel stambenog vlasništva i općenito stambeno bogatstvo značajno utječu na potencijal primjene obrnute hipoteke u snižavanju ekonomske ranjivosti starije populacije bez prodaje nekretnine, ali i bez opterećivanja buduće generacije obvezom otplate duga proizašlog iz povlačenja sredstava korištenjem obrnute hipoteke.

Więckowska (2011.) analizira ponudu, pružatelje i regulaciju proizvoda namijenjenih starijoj populaciji u povlačenju kapitala iz vrijednosti nekretnina, primarno obrnute hipoteke. Geografski je analiza usmjerena primarno na europsko područje, uz osvrt na ostatak 
svijeta. Autorica ukazuje na pozitivne strane mogućnosti pristupa i dostupnosti proizvoda za povlačenje sredstava u okviru utvrđene sheme otpuštanja kapitala na osnovi vrijednosti nekretnine, ali tek u slučaju krajnje nužde s obzirom da istodobno naglašava i ukazuje na značajnije niži najveći iznos sredstava kojem se tako može pristupiti u odnosu na punu tržišnu vrijednost nekretnine.

Reifner et al. (2009.a) ukazuju na činjenicu i poveznicu da je primjena kreditnog modela povlačenja kapitala iz vrijednosti nekretnine namijenjena starijoj populaciji odnosno doživotne ili obrnute hipoteke, niska u zemljama s kulturološkim čimbenicima koji idu u prilog vlasništva nad stambenom nekretninom kao način rješavanja stambenog pitanja, a stambena nekretnina ujedno predstavlja najvažniju imovinu pojedinca. S druge strane, primjena prodajnog modela iz okvira sheme povlačenja kapitala dokazano je viša ili visoka u društvima gdje podstanarstvo i vlasništvo nekretnina imaju podjednak status.

Slijedom prezentiranih nalaza nekih najvažnijih dosadašnjih istraživanja, može se zaključiti kako je ovo područje nepotpuno i nedovoljno kvantitativno istraženo, a primarno zbog ograničenog pristupa ili nepostojanja podataka o razmjerima primjene modela otpuštanja kapitala iz vrijednosti nekretnine na europskom području s obzirom na noviji datum uvođenja i zasad skromne primjene takve prakse na europskom području. Cilj ovoga rada je stoga pored prezentiranja takvih tehnika financiranja i njihovih prednosti i mogućnosti, detaljnije istražiti razloge i čimbenike njihove suzdržane, skromne i ograničene primjene te ukazati na potencijal šire primjene u budućnosti na području Europe, uz osvrt na ograničenja primjene.

\section{MODELI OTPUŠTANJA LIKVIDNOSTI IZ STAMBENIH NEKRETNINA NAMIJENJENIH STARIJOJ POPULACIJI U EUROPSKOJ UNIJI}

U Europskoj uniji je starijoj populaciji omogućeno povlačenje novčanih sredstava odnosno pretvaranje nelikvidnih stambenih nekretnina u novac bez preseljenja, u okviru sheme otpuštanja kapitala (engl. Equity Release Scheme), kroz kreditni (engl. Loan model, Credit agreement) i prodajni model (engl. Sale arrangement ili Home equity reversion). Financiranje prema prodajnom modelu u okviru sheme otpuštanja kapitala zabilježeno je još 1930-ih godina u Velikoj Britaniji pod nazivom «Home equity reversion». Financiranje tehnikom obrnute ili doživotne hipoteke (engl. Reverse mortgage ili Lifetime mortgage) koje proizlazi iz kreditnog modela u okviru sheme otpuštanja kapitala, namijenjeno starijim osobama i prema današnjem konceptu korištenja, razvilo se 1961. godine u SAD-u gdje je od tada pa sve do danas primjena takve tehnike financiranja $\mathrm{i}$ ostala najzastupljenija.

Shema otpuštanja kapitala namijenjena starijim vlasnicima vrijednih stambenih nekretnina u tom smislu ima određene posebnosti po kojima se razlikuje od ostalih potencijalno sličnih financijskih i/ili drugih proizvoda i usluga namijenjenih istoj ili drugim ciljnim skupinama. Uočene posebnosti pritom obuhvaćaju naznaku da je riječ o financijskom proizvodu odnosno usluzi, a ne drugoj vrsti ugovora s istom osnovom, pribavljanje sredstava u okviru ove sheme ima za cilj osigurati likvidnost starijoj populaciji primarno kao nadopunu postojećem dohotku i drugim izvorima sredstava u razdoblju umirovlje- 
nja, a u reguliranju prava u okviru ugovora koji se pritom sklapaju prednjači regulacija prava korisnika na ostanak stanovanja u predmetnoj nekretnini, načina isplate ugovorene vrijednosti korisniku i prijenosa vlasništva na pružatelja usluge (Reifner et al., 2009.a). Isplata novčanih sredstava korisniku se ovisno o modelu vrši jednokratnom isplatom ugovorenog iznosa u cijelosti ili višekratno u obliku tekućeg dohotka. Oba modela podrazumijevaju pravo doživotnog ostanka u nekretnini čija je vrijednost osnovica izračuna i isplate novčanih sredstava korisniku. Trenutak stvarnog prijenosa vlasništva na pružatelja usluge se pritom razlikuje ovisno o izabranom modelu u okviru sheme otpuštanja kapitala. S obzirom da prodajni model nije kredit pa nema niti obračuna kamate, on u biti uključuje prodaju nekretnine i isplatu vlasnika, ali uz istodobno sklapanje ugovora o najmu S novim vlasnikom pa nema preseljenja, kreditni model ili obrnuta odnosno doživotna hipoteka koja ne uključuje prodaju nekretnine s obzirom da je riječ o kreditu temeljem kojeg se obračunava dug koji se sastoji od glavnice i kamata i koji je rastući s obzirom da ne dospijeva odnosno ne zahtijeva tradicionalnu otplatu kredita sve do preseljenja, prodaje nekretnine ili smrti korisnika, u tom smislu je prihvatljivije rješenje umirovljenicima koji žele doći do likvidnosti na temelju vrijednosti nekretnine, a koju zapravo ne žele prodati. U nastavku će stoga biti detaljnije pojašnjene posebnosti i razlike ova dva modela povlačenja novčanih sredstava iz vrijednosti nekretnine, uz naglasak na njihove prednosti i manjkavosti za korisnika.

Prodajni model otpuštanja kapitala ili glavnice iz vrijednosti nekretnine u biti podrazumijeva postupak pretvaranja nelikvidne imovine u obliku stambenih nekretnina u najlikvidnije sredstvo, novac, prodajom predmetne nekretnine. Korisnik takvog modela povlačenja novčanih sredstava zapravo prodaje pružatelju ove usluge dio nekretnine koji tako stječe udjel u njenom vlasništvu ili pak cijelu nekretninu čime se vlasništvo u potpunosti prenosi na pružatelja ove usluge. Postupak se provodi na način da se dio ili cjelokupno vlasništvo nad stambenom nekretninom u kojoj korisnik ovog modela povlačenja novčanih sredstava ujedno i stanuje, prenosi ugovorom o prodaji po cijeni nižoj od trenutne tržišne vrijednosti na novog vlasnika odnosno pružatelja usluge. Korisniku se pritom ugovoreni iznos temeljem realizirane kupoprodaje stambene nekretnine uobičajeno isplaćuje u cijelosti, odjednom (engl. Lump sum). Istodobno i usporedo sa sklapanjem kupoprodajnog ugovora, korisnik zasebnim ugovorom s pružateljem ove financijske usluge uređuje pravo ostanka odnosno stanovanja u predmetnoj nekretnini prema modelu najma po kojem dotadašnji vlasnik postaje podstanar, s pravom doživotnog ostanka u njoj. Iako korisnik ove tehnike financiranja činom sklapanja ovih ugovora prestaje biti vlasnik doma u kojem ostaje stanovati kao podstanar, i dalje je dužan odgovorno se odnositi i održavati nekretninu kako joj uslijed nemara ne bi pala vrijednost te je dužan podmirivati nastale režijske troškove i sl. Pravo ostanka i zadržavanja prebivališta u predmetnoj nekretnini za korisnika u prodajnom modelu povlačenja sredstava iz vrijednosti nekretnine temelji se na ugovoru o tzv. (do)životnom najmu, a najamnina je u ovom slučaju u pravilu simbolična ili je uopće nema (primjerice, u Ujedinjenom Kraljevstvu iznosi 1 GBP mjesečno). Sklapanje dva već spomenuta, odvojena, ugovora kod prodajnog modela, ujedno definira i odvaja transakciju isplate novčanih sredstava korisniku, a kojom se realizira otpuštanje glavnice odnosno prijenos vlasništva te transakcije u okviru ugovora o najmu.

Financiranje starije populacije u okviru kreditnog modela drugi je način otpuštanja likvidnosti iz vrijednosti stambenih nekretnina tehnikom doživotne hipoteke proizašle iz 
američke prakse obrnutog hipotekarnog kreditiranja. Najznačajnije se razlikuje od prodajnog modela u tome što je ovdje riječ zapravo o kreditu, koji je osiguran hipotekom, kao što je to slučaj i kod tradicionalnih hipotekarnih kredita, međutim, od tradicionalne (unaprijedne) hipoteke se razlikuje u tome što kod obrnute hipoteke nema uobičajene otplate kredita u mjesečnim ratama, već kredit dospijeva i zatvara se tek po isteku ugovora odnosno nastupu događaja koji uvjetuju zatvaranje kredita, nakon smrti, prodaje ili preseljenja korisnika kredita, a podmiruje se iz sredstava ostvarenih prodajom nekretnine. Obrnutu hipoteku može koristiti samo stariji vlasnik nekretnine koji je posjeduje u cijelosti i u kojoj mora stanovati te imati prijavljeno prebivalište, a kreditna sposobnost dakle nije presudna za odobravanje ovog kredita s obzirom na specifičnost otplate i zatvaranja kredita, premda se u novije vrijeme i ona provjerava radi smanjenja rizika. Ako slučajno postoji kreditni teret na nekretnini, prvo se stari kredit zatvara iz sredstava odobrenih u okviru obrnute hipoteke, a tek onda s ostatkom korisnik može raspolagati bezuvjetno. Korisnici su tijekom trajanja kreditnog ugovora i dalje dužni uredno podmirivati troškove režija, plaćati porez, troškove osiguranja i ostale troškove vezane uz redovito održavanje i popravke nekretnine kako joj vrijednost uslijed nemara ne bi pala. Dodatno, za razliku od tradicionalne hipoteke kod koje se osigurava novčani tok najčešće za kupnju nekretnine, kod obrnute ili doživotne hipoteke nekretnina služi da se korisniku osigura novčani tok za raznovrsne namjene. Obrnuta hipoteka u pravilu je kredit gdje se «dug povećava, a vlasništvo opada» jer joj je svrha pribavljanje novčanih sredstava za tekuće izdatke, a vrijednost nekretnine će biti izvor sredstava za konačnu otplatu kredita, dok je kod tradicionalne, unaprijedne hipoteke obrnuto, «dug se smanjuje, a vlasništvo se povećava», jer joj je svrha stjecanje vlasništva (Tuškan, 2018:5). Kako korisnik obrnute hipoteke prima novčane isplate, tako kreditor povećava glavnicu i obračunava kamate pridodajući ih ukupnom iznosu tako odobrenog kredita (duga) i smanjuje na taj način korisnikov udjel u vlasništvu nekretnine, no dug će kreditor naplatiti iz vrijednosti nekretnine tek kad se ispune uvjeti za vraćanje odnosno zatvaranje kredita (United States Government Accountability Office, 2009:4). U nekim europskim zemljama, u kojima je omjer vrijednosti doživotne hipoteke ili inačice tog proizvoda i vrijednosti nekretnine nešto viši (može ići i do 80 \%; npr. u Danskoj) ugovara se vraćanje kredita u nekoliko tranši ili na druge specifične načine (Reifner, 2009.c:29).

Zatvaranje kredita kod obrnute hipoteke slijedi po nastupu uvjeta za zatvaranje kredita i za to je zadužen sam korisnik ako iseli iz nekretnine, a ako je u predmetnoj nekretnini korisnik živio do smrti, nasljednici su odgovorni za zatvaranje kredita i otplatu ukupno obračunatog duga. Kad nastupe uvjeti za zatvaranje kredita odnosno po isteku kredita, korisniku ili nasljednicima će ostati tek dio vrijednosti nekretnine nakon njene prodaje. Ipak, nasljednici ne moraju strahovati da će postojati dug koji će oni morati otplaćivati, a dug mogu isplatiti i na drugačiji način, iz vlastitih sredstava ili novim kreditom, ukoliko žele zadržati vlasništvo nad nekretninom. S druge strane, kreditor kod obrnute hipoteke nema pravo regresa, dakle ne može se naplatiti iz druge imovine, štednje ili ulaganja, jer je predviđeno da se dug u potpunosti vraća isključivo iz prodajne vrijednosti nekretnine. S obzirom na poseban izračun najvećeg iznosa obrnute hipoteke koji je moguće povući zbog brojnih rizika koji se moraju osigurati (uobičajeno se kreće oko odnosno ispod $50 \%$ tržišne vrijednosti nekretnine; Merton, Neng Lai, 2016.) te obračun ukupnog duga, neovisno o modelu povlačenja sredstava i dugovječnosti korisnika, vrijednost ukupnog duga nikada ne može biti veća od vrijednosti nekretnine temeljem koje se odobrava obrnuta hipoteka. 
Postoji nekoliko načina povlačenja sredstava u okviru obrnute hipoteke, a ukupan iznos koji korisnik može povući ovisi o nizu čimbenika, kao na primjer o očekivanom trajanju života, dobi, načinu isplate sredstava, kamatnoj stopi koja će se primjenjivati kod obračuna duga i ostalim troškovima kredita, procijenjenoj tržišnoj vrijednosti i kvaliteti nekretnine te o zakonski utvrđenom gornjem limitu iznosa obrnute hipoteke. Što je vlasnik nekretnine odnosno korisnik obrnute hipoteke stariji, vrijednost nekretnine veća, a kamatna stopa niža, bit će mu dostupan veći iznos sredstava. Obrnuta hipoteka općenito može se ugovoriti kao kredit ograničenog trajanja (npr. 10 godina), uz mogućnost obnavljanja ili kao doživotna hipoteka. Ako dužnik poživi duže od ugovorenog roka, kreditor ga ne može iseliti već se zaključuje novi ugovor, a doživotna hipoteka dospijeva tek nakon smrti drugog člana bračne zajednice (U.S. Department of Housing and Urban Development, 2006.). Načini isplate sredstava u okviru kreditnog modela otpuštanja kapitala temeljem ugovorene obrnute hipoteke općenito, mogu biti jednokratna isplata ukupnog iznosa odmah po odobrenju kredita, otvorena kreditna linija koja korisniku omogućava pristup sredstvima po potrebi i koja je najraširenije prihvaćen način isplate kod kreditnog modela, redovite mjesečne isplate u točno određenom razdoblju, ili kombinacija navedenih načina u različitim omjerima te uz mogućnost produženja po potrebi i redovite mjesečne isplate do preseljenja, prodaje nekretnine ili smrti, ovisno što prije nastupi i sl. (Federal Trade Commission, 2011:3; Reifner, 2009.c:29-32). Ako korisnik odluči povući sredstva odmah i u punom iznosu, dobit će najmanje sredstava u odnosu na ostale modele isplate, s obzirom da je u ovom slučaju trošak kamata najveći - cijeli iznos je isplaćen odmah pa se kamate obračunavaju na cjelokupan iznos odobrenih sredstava i za cijelo razdoblje kreditnog ugovora. Ovakav plan korištenja sredstava je najbolji izbor u slučaju kada je ostatak duga na postojeću hipoteku približno jednak iznosu dostupnom kroz ovaj plan pristupa sredstvima, a osnovni cilj je otplata postojećeg duga (Leko i Tuškan, 2009:137). 
Tablica I.: Temeljne razlike prodajnog i kreditnog modela iz sheme otpuštanja kapitala

\begin{tabular}{|c|c|c|}
\hline & Kreditni model & Prodajni model \\
\hline $\begin{array}{l}\text { Trenutak prijenosa } \\
\text { vlasništva nad nekretninom }\end{array}$ & Na kraju ugovornog odnosa & $\begin{array}{l}\text { Na početku ugovornog } \\
\text { odnosa }\end{array}$ \\
\hline $\begin{array}{l}\text { Stvarni vlasnik nekretnine } \\
\text { tijekom ugovornog odnosa }\end{array}$ & Korisnik financijske usluge & Pružatelj financijske usluge \\
\hline $\begin{array}{l}\text { Obveza održavanja } i \\
\text { popravaka nekretnine } i \\
\text { druge obveze }\end{array}$ & $\begin{array}{l}\text { Korisnik financijske usluge } \\
\text { je obvezan održavati } \\
\text { nekretninu, obavljati } \\
\text { popravke i plaćati troškove } \\
\text { osiguranja te režijske } \\
\text { troškove do kraja ugovornog } \\
\text { odnosa }\end{array}$ & $\begin{array}{l}\text { Pružatelj financijske usluge } \\
\text { kao novi vlasnik nekretnine } \\
\text { je obvezan financirati } \\
\text { popravke nekretnine, plaćati } \\
\text { troškove osiguranja i poreze, } \\
\text { a korisnik kao najmoprimac } \\
\text { plaća režijske i ostale nužne } \\
\text { troškove }\end{array}$ \\
\hline $\begin{array}{l}\text { Rast cijena na tržištu } \\
\text { nekretnina }\end{array}$ & $\begin{array}{l}\text { Ide u prilog korisnika } \\
\text { financijske usluge }\end{array}$ & $\begin{array}{l}\text { Ide u korist pružatelja } \\
\text { financijske usluge }\end{array}$ \\
\hline $\begin{array}{l}\text { Pad cijena na tržištu } \\
\text { nekretnina }\end{array}$ & $\begin{array}{l}\text { Snosi korisnik financijske } \\
\text { usluge, osim ako nije } \\
\text { drukčije navedeno u } \\
\text { ugovoru }\end{array}$ & $\begin{array}{l}\text { Snosi pružatelj financijske } \\
\text { usluge ako se radi o prodaji } \\
\text { nekretnine u cijelosti, ili i } \\
\text { pružatelj i korisnik ako se } \\
\text { radi o djelomičnoj prodaji }\end{array}$ \\
\hline $\begin{array}{l}\text { Obveze plaćanja iz ugovora } \\
\text { (novčani tok) i dospijeće }\end{array}$ & $\begin{array}{l}\text { Na početku ugovornog } \\
\text { odnosa odjednom u cijelosti } \\
\text { ili najčešće u obliku } \\
\text { otvorene kreditne linije } \\
\text { redovito mjesečno, isplaćuju } \\
\text { se sredstva korisniku. Na } \\
\text { kraju ugovornog odnosa } \\
\text { pružatelj usluge prodajom } \\
\text { nekretnine namiruje } \\
\text { sveukupno potraživanje } \\
\text { prema korisniku. }\end{array}$ & $\begin{array}{l}\text { Korisnik uobičajeno odmah } \\
\text { po sklapanju kupoprodajnog } \\
\text { ugovora dobiva cijeli } \\
\text { iznos ostvaren prodajom } \\
\text { nekretnine, a istodobno se } \\
\text { zasebnim ugovorom o najmu } \\
\text { uređuje obveza plaćanja } \\
\text { najamnine prema pružatelju } \\
\text { usluge i novom vlasniku } \\
\text { (najčešće je nema, ili je u } \\
\text { simboličnom iznosu) }\end{array}$ \\
\hline Pružatelj financijske usluge & Banke i hipotekarni kreditori & Osiguratelji \\
\hline
\end{tabular}

Izvor: Izrada autora prema Reifner, U., Cierc-Renaud, S., Perez-Carrillo, E., Tiffe, A. and Knobloch, M. (2009a). Study on Equity Release Schemes in the EU, Part 1 General Report. Institut fur Finanazdienstleistungen, Hamburg, str. 7-9.

Prodajni model se od kreditnog modela povlačenja novčanih sredstava na osnovi vrijednosti nekretnine u okviru sheme otpuštanja kapitala ustvari razlikuje u tri segmenta: pravnom, u dijelu definiranja i razgraničenja ugovornih odnosa; imovinsko-pravnom u dijelu utvrđivanja trenutka stvarnog prijenosa vlasništva te u novčanom toku (tablica I.). Dok se u prodajnom modelu vlasništvo prenosi s korisnika na pružatelja ove financijske usluge na početku, prilikom sklapanja ugovora, u kreditnom modelu vlasništvo nad domom se prenosi po dospijeću ugovornog odnosa. Dodatno, kod prodajnog modela se istodobno, ali 
zasebnim, odvojenim ugovorima, uređuje kupoprodaja odnosno prijenos vlasništva nad nekretninom i najam nekretnine. S druge strane, sva prava i obveze su kod kreditnog modela definirana u okviru jedinstvenog ugovora, no treba napomenuti kako u ovom slučaju nema niti najma. O odabranom načinu isplate novčanih sredstava ovisi konačan iznos koji korisnik sveukupno može povući u okviru sheme otpuštanja kapitala, a ovisno o modelu, isplata se vrši temeljem odobrenog kredita i tehnički je osigurana hipotekom (u kreditnom modelu) ili je pak isplata generirana realizacijom kupoprodaje nekretnine na početku ugovornog odnosa u prodajnom modelu. Pravo raspolaganja nekretninom pružatelj financijske usluge u oba slučaja tehnički ostvaruje tek nakon smrti, prodaje nekretnine odnosno preseljenja korisnika usluge, neovisno o trenutku prijenosa vlasništva i odabranom modelu financiranja. Kod kreditnog modela tek po završetku ugovornog odnosa, smrću ili preseljenjem korisnika, pružatelj ove usluge prodajom nekretnine naplaćuje kredit. U kreditnom modelu pravo doživotnog ostanka u nekretnini proizlazi iz jedinstvenog ugovora, dok se kod prodajnog modela ovo pravo uređuje ugovorom o najmu. U kreditnom modelu isplata novčanih sredstava najčešće se vrši u obliku redovitih doživotnih mjesečnih isplata ili pak isplatom cijelog iznosa odjednom u cijelosti (engl. Lump-sum) pri čemu korisnik zapravo budući novčani tok svodi na sadašnju vrijednost pa je tehnički i matematički gledano ukupni novčani iznos do kojeg korisnik može doći zapravo najmanji odnosno najnepovoljniji za korisnika, ali s čitavim iznosom može raspolagati odmah i u ovom dijelu je kreditni model najsličniji prodajnom modelu.

\section{PRIKAZ TRŽIŠTA I RAŠIRENOST MODELA OTPUŠTANJA KAPITALA IZ VRIJEDNOSTI NEKRETNINE MEĐU STARIJOM POPULACIJOM U EUROPSKOJ UNIJI}

Otpuštanje kapitala temeljem stambene nekretnine prema prodajnom i/ili kreditnom modelu namijenjeno je starijoj populaciji, s tim da se dobne granice za korištenje razlikuju od zemlje do zemlje. Takvi proizvodi su na europskom području namijenjeni uglavnom osobama starijim od 55 godina, a u nekim zemljama dobna granica za korištenje je viša. U Ujedinjenom Kraljevstvu je primjerice, dobna granica za doživotnu hipoteku 55, Irskoj i Danskoj 60, a u Njemačkoj i Italiji 65 godina, dok je u SAD-u za obrnutu hipoteku 62 godine.

S obzirom na značajnije niži maksimalan iznos sredstava koji se može pribaviti u okviru sheme otpuštanja kapitala u odnosu na procijenjenu tržišnu vrijednost nekretnine (uglavnom manji od $50 \%$, iako se u nekim europskim zemljama taj omjer, ali kod inačica ovakvih proizvoda, kreće i do 80 \%, npr. u Austriji, Danskoj), preporuka je da se ovakvom načinu financiranja pribjegava u krajnjoj nuždi odnosno tek kad se iscrpe ostale, povoljnije ili dostupnije mogućnosti i to za financiranje većih i neodgodivih financijskih izdataka. Sredstva koja korisnici povlače na ovaj način tako se najčešće koriste za financiranje troškova popravaka ili renoviranja stambenog prostora, otplatu drugih kredita, plaćanje poreza i drugih računa, pokriće troškova liječenja odnosno zdravstvene skrbi i njege te ostalih svakodnevnih životnih troškova. U pojedinim europskim zemljama postoje dodatni preduvjeti koje pojedinac mora ispuniti za apliciranje za dobivanje sredstava iz okvira sheme otpuštanja kapitala, a korištenje tako pribavljenih sredstava se pak zakonom strogo ograničava 
na unaprijed točno definirane namjene (Reifner et. al., 2009.c:29-32). Unatoč preporuci za korištenje isključivo u «krajnjoj nuždi», osim za financiranje temeljnih životnih potreba koje pojedinac nije u mogućnosti podmiriti iz tekućih primitaka, a istodobno nema drugih izvora sredstava, tako pribavljena sredstva mogu se, a pojedinci ih primjerice u SAD-u i značajnije koriste, jednostavno i za poboljšanje životnog standarda u obliku plaćanja troškova putovanja, kupovine automobila i drugih vrjednijih stvari ili za međugeneracijski prijenos štednje na ovaj način, najčešće kao financijska podrška pri stambenom zbrinjavanju djece odnosno za druge izdatke. U tom smislu, modele financiranja u okviru sheme otpuštanja kapitala trebalo bi primarno razmatrati kao komplementaran izvor financiranja tek u krajnjoj nuždi, premda imaju potencijala za primjenu i u drugačijim okolnostima (Tuškan, 2018:14). Primjerice, poželjno bi bilo imati dostupnu kreditnu liniju u okviru doživotne odnosno obrnute hipoteke za razdoblja kada druga ulaganja korisnika izgube na vrijednosti, a kako bi pojedinci mogli osigurati likvidnost i doći do novčanih sredstava za iznenadne, kapitalno zahtjevnije, tekuće izdatke, bez potrebe likvidacije ulagačkog portfelja u takvim nepovoljnim razdobljima, sve dok se tržište ne oporavi (Merton i Neng, 2016.). Primici od obrnute hipoteke su neoporezivi, a korisnik ne gubi niti stečena socijalna prava, pravo na mirovinu ili zdravstveno osiguranje.

Prodajni model financiranja starijih u okviru sheme otpuštanja kapitala nije značajnije zaživio pa je do danas reguliran i prisutan tek u manjem broju Europskih zemalja. U skromnoj primjeni odnosno korištenju prodajnog modela prednjače u Ujedinjenom Kraljevstvu i Irskoj (engl. Home reversion), dok je u ostalim zemljama u kojima je zapažena ponuda takve tehnike financiranja njeno značenje tek simbolično. Ostale zemlje u kojima je zabilježena upotreba ovog ili po značajkama sličnog prozvoda unatrag deset godina pritom obuhvaćaju Španjolsku (šp. Vivienda pension), Italiju (tal. Renta vitalicia sobre inmueble), Njemačku i Austriju (njem. Leibrente), Belgiju, Francusku i Luksemburg (fr. Vente en viager), Finsku (fin. Käänteinen asuntokauppa), a postoje naznake o upotrebi i u Mađarskoj, Bugarskoj, Rumunjskoj i Nizozemskoj (Reifner et al., 2009.c:29-32).

S druge strane, primjena obrnute hipoteke, kao izvorno američkog inovativnog hipotekarnog proizvoda namijenjenog starijim osobama proizašlog iz kreditnog modela otpuštanja likvidnosti iz vrijednosti nekretnine, porasla je unatrag desetak godina, no i danas se najviše primjenjuje na američkom području, a primarno u SAD-u i Kanadi i to pod uvriježenim nazivom «Reverse Mortgage», no zapaženije rezultate još ostvaruje i u Australiji te na Novom Zelandu. Tehnika obrnutog hipotekarnog kreditiranja proširila se i na ostatak svijeta pa se njena upotreba bilježi još i u Kini, Južnoj Koreji, Hong Kongu, Japanu, Indiji, Izraelu itd. Na Europskom području je ovaj proizvod poznatiji još i pod nazivom doživotna hipoteka, a primjena je zapaženija tek na financijskim tržištima Ujedinjenog Kraljevstva i Irske (engl. Lifetime mortgage) te Španjolske (šp. Hipoteca inversas). Vrijednost otpuštenog kapitala iz nekretnina, najviše u okviru doživotnih hipoteka, u Ujedinjenom Kraljevstvu je do 2017. godine narasla na 3 mlrd. GBP, a rastući trend korištenja modela financiranja iz ovog okvira među starijom populacijom je ponovno prisutan od 2012. godine nakon nekoliko godina pada uzrokovanog krizom (Equity Release Council, 2018.). Ostale europske zemlje, koje su uglavnom tek u novije vrijeme regulirale ponudu takve ili po karakteristikama slične tehnike financiranja no bez istaknutije upotrebe u praksi, obuhvaćaju: Belgiju (fr. Crédit hypothécaire inversé ili Crédit pension), Češku (češ. Reverznich hypoték), Dansku (dan. Friværdibelåningsprodukter), Estoniju (est. Pööratud hüpoteeklaenude), Finsku (fin. Käänteinen laina), Francusku i Luk- 
semburg (fr. Prêt viager hyphothécaire), Njemačku i Austriju (njem. Umgekehrter Hypothekenkredit), Mađarsku (mađ. Fordított jelzálogban), Italiju (tal. Prestito vitalizio ipotecario), Latviju (latv. Reversās hipotēkas), Litvu (lit. Vadinamoji atvirkštiné, hipoteka), Maltu (malt. Ipoteki invers), Nizozemsku (niz. Omgekeerde hypotheken), Poljsku (polj. Odwrócona renta hipoteczna), Portugal (port. Contrahipotecas), Rumunjsku (rum. Ipoteca inversă), Slovačku (sl. Obrátených hypoték), Sloveniju (slov. Obratne hipoteke), Švedsku (šved. Hypotekspension) itd. Ipak, prema nalazima istraživanja tržišta (Reifner et al., 2009.b:2) većina ovih zemalja do 2009. godine nije imala pravni okvir niti razvijenu praksu povlačenja sredstava pomoću modela iz okvira sheme otpuštanja kapitala. Uz iznimku Ujedinjenog Kraljevstva, ne postoje zbirni statistički podaci o korištenju ovakve prakse u ostalim europskim zemljama. Istraživanje Reifner et al. (2009.a,b,c) je jedno od rijetkih koje je u to vrijeme dalo pregled dostupnosti i zastupljenosti proizvoda iz okvira sheme otpuštanja kapitala na području Europske unije. Nije za očekivati da se stanje do danas značajnije promijenilo s obzirom da su se do unatrag nekoliko godina i na ovom tržištu značajnije osjetile posljedice zadnje financijske krize i posljedično stagnacija u razvoju i ovog segmenta financijskog tržišta. Oporavak hipotekarnog i stambenog tržišta unatrag nekoliko godina, ali i pogoršanje demografskih i nekih socio-ekonomskih varijabli vezanih uz stariju populaciju dali su novi zamah i stvorili dio preduvjeta za šire prihvaćanje, uvođenje i primjenu ovakvih proizvoda na širem europskom području. Do danas je tako pravni okvir za njihovo korištenje donesen u većini zemalja EU, a stanovništvo je manje ili više upoznato s takvim tehnikama financiranja. U nekim se zemljama koje u tom smislu predstavljaju nova tržišta, počelo nuditi takvo financiranje, primarno obrnuta ili doživotna hipoteka, no u većini, premda su takvi proizvodi dostupni, još se ne koriste uopće ili se koriste tek neznatno. Ukupna ,industrija“ obrnute hipoteke u Europskoj uniji zauzima manje od $1 \%$ ukupnog hipotekarnog poslovanja.

Premda je potencijal šire primjene ovih proizvoda neupitan ako se u obzir uzmu rezultati analize nekih najvažnijih socio-ekonomskih i demografskih pokazatelja koji idu u prilog tome: broj i udjel starije populacije koja živi ispod praga siromaštva, ovisnost starije populacije o radno-sposobnom stanovništvu, državni izdaci za mirovine, stope stambenog vlasništva itd. (Tuškan, 2018:77-79), njihova primjena je značajno potkapacitirana i ograničena, a opravdanje se najčešće pronalazi u kulturološkim čimbenicima i nevoljkosti korištenja stambenih nekretnina kao imovine koju bi buduće generacije trebale naslijediti. Pritom se najčešće niti ne sagledavaju objektivno prednosti i nedostaci korištenja takvih tehnika financiranja, čak niti kad prednosti značajnije nadmašuju potencijalne nedostatke, a u situaciji kad pojedinac, starija osoba koja je ujedno vlasnik vrijedne nekretnine, iscrpi sve druge financijske mogućnosti (ušteđevina, tekući primici, ostali izvori financiranja), a s druge strane se nađe u bezizlaznoj financijskoj situaciji koja zahtijeva značajniju financijsku podršku koju je teško osigurati na uobičajene načine preko tradicionalnih kreditnih ili drugih financijskih proizvoda i usluga. Tradicionalni krediti koje u tom smislu nude financijske institucije, starijoj populaciji su često nedostupni s obzirom na prisutnost visokog stupnja financijske isključenosti i nemogućnosti ispunjavanja strogih kreditnih kriterija kod ove ranjive kategorije u razdoblju umirovljenja kad najčešće izostanu drugi priljevi sredstava osim mirovina koje su često niske i nedostatne za podmirivanje čak i osnovnih životnih troškova, posebice ako pojedinac tijekom radnog vijeka kroz štednju i ulaganja nije osigurao ili nije mogao osigurati izvore koji bi generirali novčani tok po umirovljenju, a kojim bi mogao nadopuniti primitke na osnovi mirovine (Tuškan, 2018.). 
Zaključno, postoje brojne prednosti i koristi korištenja spomenutih proizvoda iz okvira sheme otpuštanja kapitala namijenjenih starijoj populaciji koja ujedno u visokom postotku drži vlasništvo nad vrijednim stambenim nekretninama u većini europskih zemalja, a koje se primarno ogledaju u mogućem pristupu značajnijim financijskim sredstvima u krajnjoj nuždi i koje korisniku ne stvaraju teret otplate na uobičajen način te u značajnije većoj zaštiti od zlouporabe s obzirom da je takvo financiranje dosta dobro pravno uređeno i nadzirano, a pružatelji su financijske institucije te $u$ odnosu prema primjerice praksi sklapanja ugovora o doživotnom i dosmrtnom uzdržavanju. Ipak treba uzeti u obzir i brojne negativne strane takvog financiranja. Najveći nedostatak za korisnika su visoki inicijalni troškovi ugovaranja i servisiranja kredita, nešto više kamatne stope od onih na tradicionalne hipotekarne kredite i uglavnom značajnije niži iznos od tržišne vrijednosti nekretnine koji se može tako povući. Isto tako u brojnim zemljama bi kulturološki čimbenici mogli biti presudni u korištenju takvih proizvoda s obzirom na nevoljkost žrtvovanja stambene nekretnine na ovaj način, a zbog tradicije ostavljanja nekretnine u nasljedstvo budućim generacijama, što je naglašenije u zemljama s primjerice višim udjelom stambenog vlasništva, no istodobno i višim stopama siromaštva među starijom populacijom. U prilog navedenim tvrdnjama idu i nalazi istraživanja provedenog u okviru ovoga rada, u dijelu zastupljenosti ovih proizvoda u nekim zemljama Europske unije, iz čega je razvidno da je zakonski okvir donijet, a upotreba manje ili više zaživjela, uglavnom kreditnog modela (doživotne hipoteke), u najrazvijenijim zemljama članicama koje uglavnom imaju nešto niže stope stambenog vlasništva, ali razvijenije financijske sustave. Istodobno u mnogim zemljama u kojima je naglašena kulturološka komponenta prema prethodnim istraživanjima, demografski trendovi i povezani socio-ekonomski čimbenici najčešće zahtijevaju razmatranje, a stambeno vlasništvo bi moglo imati potencijal, u primjeni takvih proizvoda za rješavanje financijskih problema starije populacije.

\section{METODOLAGIJA I REZULTATI EMPIRIJSKOG ISTRAŽIVANJA}

Korelacijska analiza u radu provedena je na statističkim podacima iz baze Eurostat-a o udjelu stambenog vlasništva (ukupno (a) i kod kategorije starije od 65 u ukupnom: kategorija domaćinstava s jednom osobom koja je stara 65 ili više godina (b) i kod domaćinstva s dvije osobe od kojih je barem jedna stara 65 ili više godina (c)) te udjelu starije populacije (65 i više godina) u ukupnom i stopama siromaštva među starijom populacijom (65 i više godina), na uzorku zemalja EU-28 u petogodišnjem razdoblju, od 2010. do 2015. godine (s obzirom na nepotpunu dostupnost novijih podataka za sve zemlje uključene u analizu), a komparativan prikaz rezultata analize nalazi se u tablici II. 
Tablica II.: Rezultati analize udjela stambenog vlasništva, korelacije udjela stambenog vlasništva i udjela starije populacije te korelacije udjela stambenog vlasništva i stope siromaštva starije populacije, 2010. - 2015., EU-28

\begin{tabular}{|c|c|c|c|}
\hline EU-28 & $\begin{array}{l}\text { Prosječan udjel } \\
\text { stambenog } \\
\text { vlasništva (u \%) } \\
\text { (rang) } \\
\end{array}$ & $\begin{array}{c}\text { Koeficijenti korelacije } \\
\text { između stope stambenog } \\
\text { vlasništva }(\mathrm{a} / \mathrm{b} / \mathrm{c}) \text { i udjela } \\
\text { starije populacije }\end{array}$ & $\begin{array}{c}\text { Koeficijenti korelacije } \\
\text { između stope stambenog } \\
\text { vlasništva }(\mathrm{a} / \mathrm{b} / \mathrm{c}) \text { i stope } \\
\text { siromaštva starije populacije }\end{array}$ \\
\hline Austrija & $56.3(27)$ & $0.25 / 0.65 / 0.77$ & $-0.14 /-0.47 /-0.69$ \\
\hline Belgija & $71.9(19)$ & $-0.21 /-0.38 / 0.93$ & $0.36 / 0.48 /-0.86$ \\
\hline Bugarska & $85.6(6)$ & $-0.92 / 0.91 / 0.82$ & $0.15 / 0.00 /-0.59$ \\
\hline Cipar & $73.3(17)$ & $-0.37 /-0.88 / 0.91$ & $-0.06 / 0.90 /-0.67$ \\
\hline Češka & $79.4(11)$ & $-0.45 / 0.83 / 0.98$ & $-0.89 /-0.15 / 0.47$ \\
\hline Danska & $65.3(25)$ & $-0.88 / 0.68 / 0.91$ & $0.76 /-0.72 /-0.98$ \\
\hline Estonija & $82.6(8)$ & $-0.74 / 0.27 / 0.95$ & $-0.71 / 0.24 / 0.98$ \\
\hline Finska & $73.6(16)$ & $-0.98 / 0.97 / 1.00$ & $0.95 /-0.82 /-0.90$ \\
\hline Francuska & $63.7(26)$ & $0.81 / 0.96 / 0.95$ & $-0.60 /-0.94 /-0.82$ \\
\hline Grčka & $75.7(14)$ & $-0.81 / 0.97 / 0.80$ & $0.64 /-0.94 /-0.96$ \\
\hline Hrvatska & $89.4(4)$ & $0.43 /-0.44 / 0.82$ & $-0.10 /-0.41 /-0.29$ \\
\hline Irska & $70.3(21)$ & $-0.71 / 0.18 / 0.98$ & $-0.47 / 0.06 / 0.65$ \\
\hline Italija & $73.2(18)$ & $-0.05 / 0.93 / 0.91$ & $0.06 /-0.89 /-0.77$ \\
\hline Latvija & $81.8(9)$ & $-0.94 / 0.73 / 0.91$ & $-0.64 / 0.41 / 0.78$ \\
\hline Litva & $91.5(2)$ & $-0.92 / 0.97 / 0.31$ & $-0.82 / 0.85 / 0.20$ \\
\hline Luksemburg & $71.0(20)$ & $0.73 / 0.85 / 0.37$ & $0.75 / 0.82 / 0.09$ \\
\hline Mađarska & $88.7(5)$ & $-0.94 / 0.78 /-0.57$ & $0.33 / 0.30 / 0.10$ \\
\hline Malta & $80.4(10)$ & $0.31 / 0.96 / 0.97$ & $0.12 / 0.41 / 0.31$ \\
\hline Nizozemska & $67.3(22)$ & $0.40 / 0.97 / 1.00$ & $-0.48 /-0.41 /-0.49$ \\
\hline Njemačka & $52.8(28)$ & $-0.97 / 0.84 / 0.57$ & $-0.86 / 0.92 / 0.70$ \\
\hline Poljska & $82.8(7)$ & $0.85 /-0.36 / 0.97$ & $-0.89 / 0.49 /-0.88$ \\
\hline Portugal & $74.7(15)$ & $-0.13 / 0.94 / 0.93$ & $0.61 /-0.61 /-0.81$ \\
\hline Rumunjska & $96.4(1)$ & $-0.23 / 0.91 /-0.26$ & $0.51 / 0.43 /-0.17$ \\
\hline Slovačka & $90.1(3)$ & $-0.54 / 0.15 / 0.60$ & $0.35 / 0.07 /-0.38$ \\
\hline Slovenija & $76.9(13)$ & $-0.71 / 0.97 / 0.80$ & $0.53 /-0.78 /-0.74$ \\
\hline Španjolska & $78.9(12)$ & $-0.74 / 0.99 / 0.93$ & $0.85 /-0.87 /-0.97$ \\
\hline Švedska & $66.2(23,24)$ & $-0.56 /-0.16 / 0.87$ & $-0.19 / 0.72 /-0.36$ \\
\hline UK & $66.2(23,24)$ & $-0.96 / 0.39 / 0.90$ & $0.81 / 0.17 /-0.94$ \\
\hline
\end{tabular}

* Vrijednosti koeficijenata korelacije pri razini signifikantnosti od 0.05 .

Izvor: izračun autora i Eurostat (2019.). Statistički podaci.

Korelacija udjela starije populacije i stope stambenog vlasništva (tablica 1., stupac 3) se povećava s dobi korisnika te je i u zemljama u kojima postoji uglavnom srednje jaka ili vrlo jaka negativna korelacija (koeficijent korelacije između -0.65 i -0.99) kad se u obzir uzme ukupna stopa stambenog vlasništva i udjela starije populacije, ona je uglavnom sred- 
nje jaka, vrlo jaka, a u nekim slučajevima i gotovo potpuno pozitivna (koeficijenti korelacije prelaze vrijednost +0.65 ) prema rezultatima testiranja povezanosti među parovima varijabli udjela starije populacije i udjela stambenog vlasništva populacije starije od 65 u ukupnom (kategorija domaćinstava s jednom osobom koja je stara 65 ili više godina i signifikantno kod domaćinstva s dvije osobe od kojih je barem jedna stara 65 ili više godina). Koeficijenti korelacije su visoki čak i u zemljama gdje su prosječne ukupne stope stambenog vlasništva kao načina stanovanja nešto niže ili imaju podjednak udjel u ukupnom načinu stanovanja čitave populacije kao i najam. S obzirom da podaci o načinu stanovanja među starijom populacijom nisu dostupni, već samo o participaciji stambenog vlasništva ove kategorije u ukupnom stambenom vlasništvu čitave populacije pa je taj podatak i uključen u analizu, ne mogu se donijeti precizniji zaključci o povezanosti varijabli bez rezultata takve analize koja bi se konkretnije odnosila isključivo na stariju populaciju. Kod parova varijabli udjela stambenog vlasništva (ukupno i starijih od 65 u ukupnom) i stope siromaštva među populacijom starosti 65 i više godina zamjetna je srednje jaka ili vrlo jaka negativna korelacija (tablica 1., stupac 4), a s druge strane nema značajnije povezanosti ni razlika u povezanosti koja je prethodno zamijećena kod stambenog vlasništva starije populacije u ukupnom u odnosu kada je u testiranje uključena stopa ukupnog stambenog vlasništva čitave populacije. Ovaj nalaz upućuje na neiskorišten potencijal uključivanja stambenih nekretnina općenito u rješavanje financijskih problema starije populacije.

S druge strane, kulturološki čimbenici predstavljaju najznačajniju prepreku za uvođenje ili intenzivnije korištenje takvih proizvoda unatoč očitom potencijalu za primjenu ovakvih proizvoda u rješavanju financijskih problema starije populacije, koji je prema podacima Eurostat-a (2018.) za 2017. godinu na uzorku EU-28, naglašeniji u zemljama s primjerice višim udjelom stambenog vlasništva (prosjek oko $75 \%$, raspon od $53 \%$ do $97 \%$ ), no istodobno i višim stopama siromaštva među starijom populacijom (u prosjeku svaka peta starija osoba u EU je izložena riziku siromaštva, raspon od oko $7 \%$ do $40 \%$ ), npr. u posttranzicijskim zemljama i drugim zemljama jugoistočne Europe pa tako i u Republici Hrvatskoj, u kojima je primjena ovih proizvoda niska ili ne postoji, ali i nepovoljnijim drugim demografskim i socio-ekonomskim pokazateljima (viši udjel starije populacije (prosjek oko $19 \%$, raspon od oko $13 \%$ do $22 \%$ ), ali i niska razina financijske pismenosti, visoka proračunska ovisnost mirovina, niske mirovine itd.), a koji su općenito promatrano nepovoljni u većem dijelu Europske unije. U prilog ovoj tvrdnji idu i nalazi istraživanja provedenog u okviru ovoga rada, u dijelu zastupljenosti ovih proizvoda u pojedinim zemljama Europske unije, iz čega je razvidno da je zakonski okvir donijet, a upotreba manje ili više zaživjela, ponajprije kreditnog modela ili doživotne hipoteke, tek u najrazvijenijim zemljama članicama, koje pak uglavnom imaju nešto niže stope stambenog vlasništva, ali razvijenije financijske sustave. Šire razmatranje ostalih demografskih i socio-ekonomskih čimbenika zasigurno bi dalo još potpuniju sliku o mogućnostima, načinima, prilikama i potencijalu korištenja stambenih nekretnina kao izvora financiranja.

U Republici Hrvatskoj potencijal za primjenu analiziranih instrumenata i modela povlačenja sredstava iz vrijednosti nekretnina, primarno obrnute hipoteke, zasigurno postoji ako se zanemare kulturološki čimbenici i promatraju isključivo prethodno spomenuti i analizirani statistički pokazatelji, a sa stajališta potrebe nadopune tekućih primanja umirovljenika uslijed njihove nedostatnosti ili izostanka istih, uz istodobno ispunjen preduvjet vlasništva nad stambenom nekretninom. Ukoliko nemaju ušteđevine, a pristup tradicionalnim kreditima je ograničen, postojeća financijska alternativa starijoj populaciji su ugovori o dosmrtnom i doživotnom uzdržavanju koji zbog pomanjkanja zakonske zaštite korisnika 
i čestih zlouporaba takvih ugovora od strane pružatelja značajno ograničavaju interes korisnika pa bi proizvod načelno sličan po financijskom ishodu za korisnika, a koji je precizno zakonski uređen i kvalitetno nadziran u postupku provedbe uz istodobnu mogućnost ostanka u nekretnini možda bio prihvatljivije rješenje u situacijama kad potencijalni korisnik razmišlja o nužnosti korištenja kreditnih izvora financiranja bez obveze otplate za života. Razina i rast cijena nekretnina idu u prilog prednosti i potencijalu korištenja stambenih nekretnina za povlačenje financijskih sredstava na ovaj način. Ipak, postoje značajne razlike u takvom potencijalu unutar zemlje s obzirom da se cijene stambenih nekretnina (po $\mathrm{m}^{2}$ ) značajno razlikuju odnosno značajnije su više na području Grada Zagreba i u ostalim većim gradovima posebice u Primorju i Istri te priobalnoj Dalmaciji s obzirom na utjecaj bavljenja turizmom i atraktivnost takvih lokacija, u usporedbi s ruralnim, zabačenijim ili manje atraktivnim dijelovima zemlje za život (npr. u Lici i Gorskom kotaru, Slavoniji i sl.), a na što upućuju i utječu ili su pak posljedica i negativni demografski pokazatelji. O tome posljedično ovisi apsolutni iznos sredstava koji bi se mogao povući iz vrijednosti nekretnina i bio dostupan korisnicima u slučaju da se odluče na takav način financiranja, ali uzimajući u obzir i ostale čimbenike koji, osim uobičajeno zakonski utvrđene ograničene najveće moguće vrijednosti kredita, a unutar tog limita to je oko ili ispod $50 \%$ procijenjene tržišne vrijednosti nekretnine, utječu na konačan ishod pri izračunu, kao na primjer ugovorena dinamika isplate sredstava, kamatne stope (referentan kamatnjak pri izračunu je najčešće onaj na državne obveznice istog dospijeća), očekivano trajanje života, starost korisnika u trenutku korištenja takvih proizvoda i sl. U tablici III. je dan prikaz izabranih pokazatelja stanja na domaćem stambenom tržištu (zbog nepostojanja službenih podataka za cjelokupno stambeno tržište, prikazani su podaci o cijenama koji se odnose na novogradnju), broju osiguranika i korisnika mirovina, a koji pored prethodno analiziranih ostalih socio-ekonomskih čimbenika, pogotovo rasta stope rizika od siromaštva među populacijom starijom od 65 godina (s 23,4 \% u 2013. na 26,5 \% u 2016.; DZS, 2018:198), ukazuju na financijski potencijal proizvoda za povlačenje novčanih sredstava iz vrijednosti nekretnina.

Tablica III.: Izabrani pokazatelji stambenog tržišta i mirovinskog sustava u Republici Hrvatskoj

\begin{tabular}{|c|c|c|c|c|c|c|}
\hline & 2013. & 2014. & 2015. & 2016. & 2017. & 2018. \\
\hline $\begin{array}{l}\text { Prosječna cijena prodanih } \\
\text { novoizgrađenih stambenih nekretnina } \\
\left(H R K / m^{2}\right)-R H\end{array}$ & 10.426 & 10.524 & 10.688 & 10.034 & 10.734 & 11.466 \\
\hline $\begin{array}{l}\text { Prosječna cijena prodanih } \\
\text { novoizgrađenih stambenih } \\
\text { nekretnina }\left(H R K / m^{2}\right)-Z a g r e b\end{array}$ & 11.104 & 11.958 & 11.797 & 10.445 & 12.098 & 12.749 \\
\hline $\begin{array}{l}\text { Prosječna cijena prodanih } \\
\text { novoizgrađenih stambenih } \\
\text { nekretnina }\left(H R K / \mathrm{m}^{2}\right)-\text { Ostalo }\end{array}$ & 9.486 & 9.280 & 9.617 & 9.582 & 9.679 & 10.310 \\
\hline $\begin{array}{l}\text { Broj osiguranika u mirovinskom } \\
\text { sustavu (stanje na } 31.12 ., \text { u } 000 \text { ) }\end{array}$ & 1.401 & 1.397 & 1.414 & 1.440 & 1.475 & 1.507 \\
\hline $\begin{array}{l}\text { Broj korisnika mirovina (stanje na } 31 . \\
12 ., \text { u } 000 \text { ) }\end{array}$ & 1.182 & 1.223 & 1.226 & 1.233 & 1.232 & 1.236 \\
\hline
\end{tabular}

Izvor: Državni zavod za statistiku (2018). Statistički ljetopis Republike Hrvatske 2018. i Hrvatski zavod za mirovinsko osiguranje (2019). Službeni podaci. 
Uz naznake za povećanje dobne granice za ulazak u mirovinu, produženje životnog vijeka, probleme održivosti postojećeg mirovinskog sustava i nepovoljnih demografskih kretanja (iseljavanje, prirodno kretanje stanovništva), visokog udjela starije populacije (18 \% stariji od 65, $24 \%$ stariji od 60 prema posljednjem popisu stanovništva iz 2011; DZS, 2018: 110), visoke stope nezaposlenosti, nesklada rasta plaća, mirovina i ostalih socijalnih primanja s jedne te realnih troškova života, s druge strane i sl., budućoj starijoj populaciji bi kvaliteta života i financijska situacija mogla biti dodatno značajnije narušena pa bi inovirani financijski proizvodi kao što je to obrnuta hipoteka mogli pomoći u pristupu dodatnim novčanim sredstvima u težim financijskim situacijama i imati veći potencijal primjene $u$ budućnosti, nego što je za očekivati u postojećim okolnostima uslijed naglašenijeg utjecaja spomenutih kulturoloških čimbenika.

\section{ZAKLJUČAK I PREPORUKE ZA BUDUĆA ISTRAŽIVANJA}

Postoje brojne prednosti i koristi korištenja spomenutih proizvoda iz okvira sheme otpuštanja kapitala namijenjenih starijoj populaciji, koja ujedno u visokom postotku drži vlasništvo nad vrijednim stambenim nekretninama u većini europskih zemalja. Prema povezanim nepovoljnim demografskim i socio-ekonomskim kretanjima brojne europske zemlje imaju vidljiv potencijal za primjenu proizvoda za povlačenje financijskih sredstava na osnovi vlasništva nad stambenim nekretninama u rješavanju financijskih problema starije populacije. U takvim okolnostima prednosti se primarno ogledaju u mogućem pristupu značajnijim financijskim sredstvima u krajnjoj nuždi i kad ne postoje ili su iscrpljeni drugi izvori sredstava, a ovakvi proizvodi korisniku ne stvaraju teret otplate na uobičajen način te u značajnije većoj mjeri štite korisnika od zlouporabe u odnosu prema drugim, primjerice spomenutim nefinancijskim proizvodima koji bi za korisnika trebali polučiti isti učinak, a za koje pak ne postoji uređeno tržište. Unatoč tome, kulturološki čimbenici i nevoljkost korištenja stambenih nekretnina na ovaj način značajnije ograničavaju ponudu i potražnju ovakvih proizvoda, s obzirom da tradicionalno u brojnim europskim zemljama postoje očekivanja i podrazumijeva se ostaviti ih budućim generacijama u nasljedstvo, što pak upotreba ovakvih financijskih proizvoda de facto onemogućava. Dodatno, i drugi identificirani najznačajniji negativni aspekti značajnije ponderiraju prilikom odlučivanja o isplativosti ponude i korištenja tehnika financiranja razmatranih u ovom radu. Analiza zastupljenosti ovih proizvoda u pojedinim zemljama Europske unije ukazala je stoga da je zakonski okvir donesen, a upotreba manje ili više zaživjela, ponajprije kreditnog modela ili doživotne hipoteke, tek u najrazvijenijim zemljama članicama, koje uglavnom imaju nešto niže stope stambenog vlasništva, ali visok udjel starije populacije i razvijenije financijske sustave. Buduća istraživanja bi trebala dati odgovor na pitanja o utjecaju i značajnosti demografskih i socio-ekonomskih varijabli na korištenje obrnute hipoteke i drugih modela povlačenja sredstava iz vrijednosti nekretnine i obrnuto, o učincima primjene povlačenja sredstava iz okvira sheme otpuštanja kapitala neovisno o modelu na kretanja navedenih varijabli. Zbog ograničene dostupnosti ili nedostatka kvantitativnih podataka i/ili vremenske serije o konkretnoj primjeni modela, primjerice u zemljama Europske unije, zbog novijeg datuma njihove primjene i dosada skromne i ograničene primjene, detaljniju, potpuniju i širu analizu iz koje bi se mogli izvući konkretniji i precizniji zaključci zasad nije moguće provesti. 


\section{LITERATURA:}

1. Coda Moscarola, F., d'Addio, A. C., Fornero, E., Rossi, M. C. (2015). Reverse mortgage: a tool to reduce old age poverty without sacrificing social inclusion. U: Borsch-Supan, A., Weber, G., Kneip, T., Litwin, H., Mick, M., Weber, G., ed.: Ageing in Europe - Supporting Policies for an Inclusive Society. Chapter: 21, Walter de Gruyter GmbH \& Co., Berlin/ Boston, str. 235-244.

2. Državni zavod za statistiku (2018). Statistički ljetopis Republike Hrvatske 2018.

3. Equity Release Council (2018). Equity Release Market Report - Autumn 2018.

4. Eurostat (2019). Statistički podaci.

5. Federal Trade Commission (2011). Reverse mortgages (dostupno na: https://www.consumer.ftc.gov/articles/pdf-0058-reverse-mortgages.pdf, pristupano 20. siječnja 2019.).

6. Gwizdala, J. (2015). Equity release schemes on selected housing loan markets across the world. RP of Wroclaw University of Economics. Nr. 381. U: Jajuga, K., Ronka-Chmielowiec, W., ed.: Financial Investment and Insurance-Global Trends and the Polish Market. Publishing House of Wroclaw University of Economics, str. 72-85.

7. Hrvatski zavod za mirovinsko osiguranje (2019). Službeni podaci.

8. Leko, V., Tuškan, B. (2009). Financiranje osoba starije životne dobi tehnikom obrnute hipoteke. U: Računovodstvo i financije. god. 55, br. 6, HZRIF, Zagreb, str. 133-142.

9. Merton, R., Neng Lai, R. (2016). On an Efficient Design of the Reverse Mortgage: Structure, Marketing, and Funding, Massachusetts Institute of Technology and University of Macau.

10. Reifner, U., Cierc-Renaud, S., Perez-Carrillo, E., Tiffe, A. and Knobloch, M. (2009 a). Study on Equity Release Schemes in the EU, Part 1 General Report. Institut fur Finanazdienstleistungen, Hamburg.

11. Reifner, U., Cierc-Renaud, S., Perez-Carrillo, E., Tiffe, A. and Knobloch, M. (2009 b). Study on Equity Release Schemes in the EU, Part II Country Reports. Institut fur Finanazdienstleistungen, Hamburg.

12. Reifner, U., Cierc-Renaud, S., Perez-Carrillo, E., Tiffe, A. and Knobloch, M. (2009 c). Study on Equity Release Schemes in the EU, Part 1II, Annexes. Institut fur Finanazdienstleistungen, Hamburg.

13. Tuškan, B. (2018). Uloga i potencijal obrnute hipoteke u ponudi štedno-ulagačkih proizvoda na financijskom tržištu. U: Zbornik međunarodne znanstveno-stručne konferencije: Dani hrvatskog osiguranja 2018. Hrvatski ured za osiguranje, Hrvatska gospodarska komora, str. 70-83.

14. U.S. Department of Housing and Urban Development (2006). Top Ten Things to Know if You're Interested in a Reverse Mortgage (dostupno na: www.hud.gov, pristupano: 20. siječnja 2019.).

15. United States Government Accountability Office (2009). Reverse Mortgages: Product Complexity and Consumer Protection Issues Underscore Need for Improved Controls over Counseling for Borrowers, Report to Congressional Requesters, GAO-09-606.

16. Więckowska, B. (2011). Reverse mortgage - rozwiqzania prawne i instytucjonalne na wybranych rynkach. PIU, Varšava, str. 1-48. 